\title{
Interspecific hybrids of wild Cucumis species ('Fian' and 'Fimy'): new rootstocks for melon highly resistant to biotic soil stress
}

\author{
C. Gisbert ${ }^{1}$, A. Cáceres¹, G. Perpiñà ${ }^{1}$, A. Garcés-Claver², V. González², ML. Gómez- \\ Guillamón ${ }^{3}$ and B. Picó ${ }^{1}$
}

1 COMAV, Universitat Politècnica de València, Camino de Vera s/n Ed8E esc.J, 46022 València, Spain; ${ }^{2}$ CITA, Centro de Investigación y Tecnología Agroalimentaria de Aragón. Instituto Agroalimentario de Aragón - IA2 (CITA-Universidad de Zaragoza), Zaragoza, Spain; ${ }^{3}$ IHSM La Mayora, UMA-CSIC, Algarrobo,29750-Málaga, Spain.

\begin{abstract}
Two hybrids, 'UPV-FA' and 'UPV-FMy', hereinafter 'Fian' and 'Fimy', were obtained by crossing the wild Cucumis species C. ficifolius with C. anguria and C. myriocarpus, respectively. These species are known to be resistant to nematodes. The hybrids have been tested against the main melon soil borne and aerial fungal pathogens. Both were highly resistant to Macrophomina phaseolina and to Fusarium oxysporum f. sp. melonis (Fom) race 1.2 (wilting isolate), and moderately resistant to Fom 1.2 (yellowing isolate) and to Monosporascus cannonballus. 'Fimy' was highly resistant to powdery mildew races 2 and 5, and 'Fian' was highly and moderately resistant to these races, respectively. These hybrids were previously evaluated as rootstocks for melon in greenhouses and experimental fields with good results (adequate compatibility, growth development and production, and no negative impact on fruit quality). This behaviour has been now confirmed in commercial fields. The same grafting combinations were used: as scion the muskmelon cv. 'Vendrantais', a Charentais type, and the cv. 'Finura', a Piel de Sapo type, and as rootstocks 'Fian', 'Fimy' and two commercial rootstocks 'Cobalt' (Cucumis maxima x Cucumis moschata) and '64-376' (Cucumis melo). As in previous assays, fruit from plants grafted onto 'Cobalt' yielded larger fruits, with wider seminal cavities. In fruit harvested from plants grafted onto 'Fian', 'Fimy' or onto the other Cucumis rootstock some mild differences that do not affect the market quality of fruit were found. All these results confirm the suitability of both hybrids as rootstocks for melon: they show good grafting performance, with reduced impact on fruit quality compared to Cucurbita rootstocks, and better resistance to the fungal pathogens that limit melon production worldwide.
\end{abstract}

Keywords: C. ficifolius, C. anguria, Piel de sapo, Charentais, grafting.

\section{INTRODUCTION}

Grafting plants onto resistant rootstocks is used worldwide to cope with biotic and abiotic stresses, such as soil-borne diseases, drought, salinity, and extreme temperatures. The most common rootstocks used for Cucurbitaceae crops, are the interspecific hybrids Cucurbita maxima Duchesne x Cucurbita moschata Duchesne (Davis et al., 2008) due to their good emergence performance (with long and thick hypocotyls that facilitate grafting) and their tolerance to biotic and abiotic stresses. Cucurbita hybrids have, however, some important shortcomings: they are not resistant to nematodes (Cohen et al., 2014; Ozarslandan et al., 2011); their excess of vigour cause sometimes a delay in scion flowering and fruit ripening (Soteriou et al., 2016), anł often, cause negative impacts on fruit quality (Leonardi et al., 2017). In melon (Cucumis melo L.), an increase of fruit size and seed cavity (Verzera et al., 2014) or modifications of flesh firmness (Colla et al., 2006; Zhao et al., 2011) as a result of grafting have been described. Vitrescence (Jang et al., 2014), flesh colour variations, and 
changes in $\mathrm{pH}$ and soluble solids content have also been reported (Colla et al., 2006; Verzera et al., 2014).

We obtained two new interspecific Cucumis hybrids: 'UPV-FA' (C. ficifolius x $C$. anguria) and 'UPV-FMy' (C. ficifolius x C. myriocarpus) (Cáceres et al., 2017) herein after, 'Fian' and 'Fimy' with good characteristics to be used as melon rootstocks (Cáceres et al., 2017). Both were highly resistant to Macrophomina phaseolina and to Fusarium oxysporum f. sp. melonis (Fom) race $1.2 \mathrm{~W}$ (wilting pathotype), and moderately resistant to Fom $1.2 \mathrm{Y}$ (yellowing pathotype) and to Monosporascus cannonballus. 'Fimy' was highly resistant to powdery mildew races 2 and 5, and 'Fian' was highly and moderately resistant to these races, respectively. These hybrids were previously evaluated as rootstocks for melon in greenhouses and experimental fields with good results (adequate compatibility, growth development and production, and no negative impact on fruit quality). The aim of this work was to confirm their Fusarium oxysporum resistance and evaluate their performance under commercial field conditions.

\section{MATERIALS AND METHODS}

Plant material: As rootstocks. 'Fian' and 'Fimy' and the commercial rootstocks 'Cobalt' (C. maxima x C. moschata) and '64-376' (C. melo) were used. The cvs. Finura (Piel de Sapo) and cv. Vedrantais (Charentais) were used as scions. Plants were grafted in a commercial nursery using the cleft procedure and were transplanted to soil in a field for commercial production of Valencia.

Inoculations: Plants of 'Fian' and 'Fimy' were artificially inoculated with both conidial suspension of $3 \times 10^{6} \mathrm{cel} / \mathrm{mL}$ of Fom $1.2 \mathrm{~W}$ and Fom $1.2 \mathrm{Y}$ isolates. Inoculation was carried out by 2 min of root immersion of plantlets at two expanded cotyledons stage (12 plants per accession). They were taken to the growth chamber for 30 days at $26^{\circ} \mathrm{C}$. Response of plants was evaluated at 7, 14, 21 and $28 \mathrm{dpi}$, measuring the degree of symptomatology of the seedlings. A visual scale from 1 to 4 was employed: $1=$ no disease; $2=$ stunting and leaf damages up to $50 \%$; $3=$ plant yellowing and wilt, root damages; $4=$ dead plant. Plant score as 1 was considered to be highly resistant, between 1 and 2 were considered resistant and those with scores higher than 2 were considered susceptible. 'Charentais T' was used as susceptible control to both Fom1.2 pathotypes. Dead plants were collected to be taken to the laboratory and processed, to check the cause of death and fulfill Koch's postulates.

Quality analysis: Marketable fruit were collected and analysed for fruit quality parameters (Table 1) as described in Cáceres et al. (2017).

\section{RESULTS AND DISCUSSION}

'Fian' and 'Fimy' were resistant and highly resistant to Fom1.2 W, respectively (1.4 \pm 1.1 for 'Fian' and $1 \pm 0.0$ for 'Fimy') (Fig. 1). Also, when 'Fian' and 'Fimy' were tested against Fom1.2 Y, both hybrids were evaluated as resistant with values of $2.0 \pm 1.5$ and $1.9 \pm 1.4$, respectively. As expected, the susceptible genotype 'Charentais T' behaved as susceptible to Fom1.2 W and Fom1.2 Y.

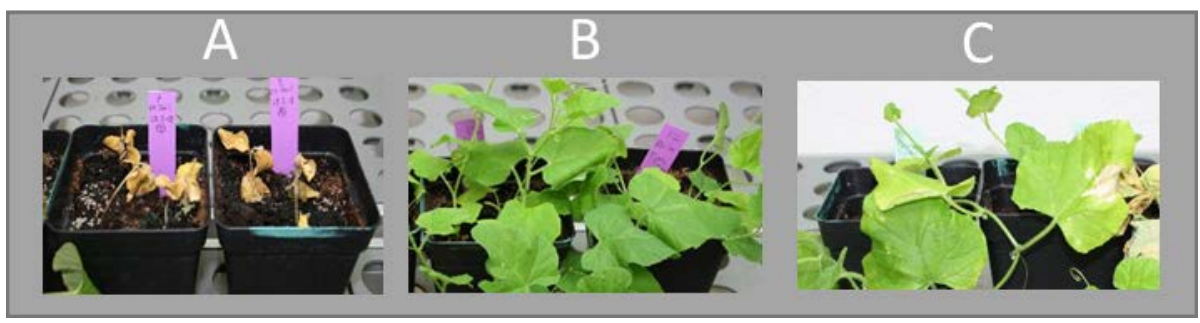

Figure 1. Plants of A) 'Charentais T', B) 'Fimy', C) 'Fian' inoculated with Fom $1.2 \mathrm{~W}$ isolate after 28 days of inoculation. 
Data of fruit quality are shown in Table 1. Regarding fruit quality of 'Finura' (Piel de Sapo), larger fruits were found when the Cucurbita hybrid 'Cobalt' was used as rootstock. These fruits also displayed wider seed cavities in comparison with fruit from ungrafted plants, as reported in other works that used Cucurbita hybrids (Verzera et al., 2014. This effect also occurred in fruit collected from the two new wild Cucumis rootstocks. The commercial melon rootstock '64-376' did not caused more impact than a firmer flesh.

Similarly, larger fruits of 'Vedrantais' with wider seed cavities were observed in plants grafted onto 'Cobalt'. The cantaloupe scion was more affected by the Cucurbita rootstock than the Piel de sapo scion, since fruits with thicker, but softer rind were produced. The effects of the Cucumis rootstocks onto the 'Vedrantais' fruits were also less important. Despite all rootstocks significantly reduced Brix degree of 'Vedrantais' fruits, they were still sweet enough for commercial purposes.

Table 1. Quality traits of melon fruit cv. 'Finura' (Piel de Sapo) and cv. 'Vedrantais' (Charentais) harvested from ungrafted and plants grafted onto Cobalt (C. maxima x $C$. moschata); '64-376' (C. melo); 'Fian' (C. ficifolius x C. anguria) and 'Fimy' (C. ficifolius x $C$. myriocarpus); NG: non-grafted.

\begin{tabular}{|c|c|c|c|c|c|}
\hline Scion & \multicolumn{5}{|c|}{ 'Finura' } \\
\hline Trait/Rootstock & NG & 'Cobalt' & '64-376’ & 'Fian' & 'Fimy' \\
\hline Fruit weight (g) & $2174.00 \mathrm{a}$ & $2490.28 b$ & 2151.40a & $2264.82 \mathrm{ab}$ & $2154.77 a$ \\
\hline Fruit length $(\mathrm{cm})$ & $21.15 \mathrm{ab}$ & $21.77 \mathrm{~b}$ & $20.78 \mathrm{a}$ & $21.42 \mathrm{ab}$ & $20.61 \mathrm{a}$ \\
\hline Fruit width $(\mathrm{cm})$ & $14.55 a$ & $14.76 a$ & $15.6 \mathrm{~b}$ & $14.92 \mathrm{ab}$ & $14.96 \mathrm{ab}$ \\
\hline $\begin{array}{l}\text { Rind thickness } \\
(\mathrm{mm})\end{array}$ & $4.72 \mathrm{a}$ & $4.90 \mathrm{a}$ & $4.61 \mathrm{a}$ & $4.66 a$ & $4.58 \mathrm{a}$ \\
\hline $\begin{array}{l}\text { Flesh thickness } \\
(\mathrm{mm})\end{array}$ & $37.15 a$ & $37.59 \mathrm{a}$ & $36.23 a$ & $44.26 a$ & $35.19 a$ \\
\hline Cavity width (mm) & $59.14 a$ & $68.82 \mathrm{~b}$ & 63.19ab & $65.97 \mathrm{~b}$ & $66.47 \mathrm{~b}$ \\
\hline Rind firmness & 13 & 13 & 13 & 13 & 13 \\
\hline Flesh firmness & $2.78 \mathrm{ab}$ & $2.62 \mathrm{a}$ & $3.15 c$ & $2.58 \mathrm{a}$ & $2.97 \mathrm{bc}$ \\
\hline $\begin{array}{l}\text { Total Soluble } \\
\text { solids (ํㅡrix) }\end{array}$ & 14.88ab & $14.80 \mathrm{ab}$ & $14.41 \mathrm{a}$ & $15.39 \mathrm{~b}$ & $14.81 \mathrm{ab}$ \\
\hline $\mathrm{pH}$ & $5.92 a$ & $5.90 a$ & $5.94 a$ & $5.95 a$ & $5.96 a$ \\
\hline Hunter L & $62.60 \mathrm{a}$ & $63.30 \mathrm{a}$ & $63.61 \mathrm{a}$ & $64.00 \mathrm{a}$ & $64.21 \mathrm{a}$ \\
\hline Hunter a & $-2.62 a$ & $-2.48 a b$ & $-2.44 a b$ & $-2.14 b$ & $-2,66 a$ \\
\hline Hunter b & $9.43 a$ & $8.98 \mathrm{a}$ & $9.18 \mathrm{a}$ & $9.14 \mathrm{a}$ & $9.62 \mathrm{a}$ \\
\hline Scion & \multicolumn{5}{|c|}{ 'Vedrantais' } \\
\hline Trait/Rootstock & NG & 'Cobalt' & '64-376’ & 'Fian' & 'Fimy' \\
\hline Fruit weight (g) & $646.10 \mathrm{a}$ & $743.80 \mathrm{~b}$ & $682.83 \mathrm{ab}$ & $645.8 a$ & $625.40 \mathrm{a}$ \\
\hline Fruit lenght $(\mathrm{cm})$ & $9.88 \mathrm{a}$ & $10.13 a$ & $10.07 \mathrm{a}$ & $10.19 \mathrm{a}$ & $10.00 \mathrm{a}$ \\
\hline Fruit width (cm) & $11.00 \mathrm{a}$ & $11.67 \mathrm{a}$ & $11.16 \mathrm{a}$ & $10.86 a$ & $10.87 a$ \\
\hline $\begin{array}{l}\text { Rind thickness } \\
(\mathrm{mm})\end{array}$ & $2.99 a$ & $2.99 a$ & $3.07 a$ & $3.07 a$ & $2.99 a$ \\
\hline $\begin{array}{l}\text { Flesh thickness } \\
(\mathrm{mm})\end{array}$ & $25.54 a$ & $26.88 \mathrm{~b}$ & $26.71 b$ & $25.44 \mathrm{ab}$ & $25.68 \mathrm{ab}$ \\
\hline Cavity width (mm) & $50.73 a$ & $54.58 b$ & $48.96 a$ & $49.11 \mathrm{a}$ & $48.56 a$ \\
\hline Rind firmness & $12.26 \mathrm{~b}$ & $11.18 \mathrm{a}$ & $12.36 \mathrm{~b}$ & $12.70 \mathrm{~b}$ & $12.60 \mathrm{~b}$ \\
\hline Flesh firmness & $1.95 a$ & $1.93 a$ & $1.65 a$ & $1.68 \mathrm{a}$ & $1.90 \mathrm{a}$ \\
\hline
\end{tabular}




\begin{tabular}{|l|c|c|c|c|c|}
\hline $\begin{array}{l}\text { Total Soluble } \\
\text { solids (으ix) }\end{array}$ & $14.44 \mathrm{~b}$ & $13.77 \mathrm{a}$ & $13.45 \mathrm{a}$ & $13.59 \mathrm{a}$ & $13.41 \mathrm{a}$ \\
\hline $\mathrm{pH}$ & $6.11 \mathrm{a}$ & $5.92 \mathrm{a}$ & $6.16 \mathrm{a}$ & $6.13 \mathrm{a}$ & $6.14 \mathrm{a}$ \\
\hline Hunter L & $56.58 \mathrm{bc}$ & $56.96 \mathrm{c}$ & $54.71 \mathrm{ab}$ & $55.60 \mathrm{abc}$ & $54.37 \mathrm{a}$ \\
\hline Hunter a & $11.88 \mathrm{a}$ & $12.24 \mathrm{a}$ & $11.75 \mathrm{a}$ & $12.00 \mathrm{a}$ & $12.12 \mathrm{a}$ \\
\hline Hunter b & $24.46 \mathrm{abc}$ & $24.92 \mathrm{c}$ & $23.60 \mathrm{a}$ & $24.55 \mathrm{bc}$ & $23.81 \mathrm{ab}$ \\
\hline
\end{tabular}

\section{CONCLUSION}

The results obtained in this assay confirm those obtained previously in experimental fields and the suitability of both hybrids 'Fian' and 'Fimy' as rootstocks for melon. In comparison to Cucurbita and Cucumis commercial rootstocks, a reduced impact on fruit quality and better resistance to fungal pathogens were found in the new wild Cucumis hybrids.

\section{ACKNOLEDGEMENTS}

This study was partially supported by the Spanish Ministerio de Economía y Competitividad project AGL2014-53398-C2- 1 and 2-R, by the Spanish Ministerio de Ciencia, Innovación y Universidades project AGL2017-85563-C2-1 and 2-R and by the Conselleria d'Educació, Investigació, Cultura i Esports de la Generalitat Valenciana PROMETEO project for excellence groups/2017/078 (cofunded with FEDER funds).

\section{Literature cited}

Cáceres, A., Perpiña, G., Ferriol, M., Picó, M.B., and Gisbert, C. (2017). New Cucumis Rootstocks for Melon: 'UPV-FA' and 'UPV-FMy.' HortScience 52(5), 792-797. https://doi.org/10.21273/HORTSCI11791-17.

Cohen, R., Tyutyunik, J., Fallik, E., Oka, Y., Tadmor, Y., and Edelstein, M. (2014). Phytopathological evaluation of exotic watermelon germplasm as a basis for rootstock breeding. Sci. Hortic. 165, 203-210.

https://doi.org/10.1016/j.scienta.2013.11.007.

Colla, G., Rouphael, Y., Cardarelli, M., Massa, D., Salerno, A., and Rea, E. (2006). Yield, fruit quality and mineral composition of grafted melon plants grown under saline conditions. J. Hortic. Sci. Biotech. 81(1), 146-152. https://doi.org/10.1080/14620316.2006.11512041.

Davis, A. R., Perkins-Veazie, P., Hassell, R., Levi, A., King, S. R., \& Zhang, X. (2008). Grafting effects on vegetable quality. HortScience 43(6), 1670-1672.

Jang, Y., Huh, Y.C., Park, D.K., Mun, B., Lee, S., and Um, Y. (2014). Greenhouse evaluation of melon rootstock resistance to Monosporascus root rot and vine decline as well as of yield and fruit quality in grafted 'Inodorus' melons. Korean J. Hortic. Sci. 32(5), 614-622. https://doi.org/10.7235/hort.2014.14065.

Leonardi, C., Kyriacou, M.C., Gisbert, C., Oztekin, G.B., Mourão, I., and Rouphael, Y. (2017). Quality of Grafted Vegetables. In Vegetable Grafting: Principles and Practices, 1 st edn, G. Colla, F. Pérez-Alfocea and D. Schwarz, eds. (Boston, MA, USA: CABI), p.216-244.

Özarslandan, A., Sögüt, M.A., Yetisir, H., and Elekcioğlu, I.H. (2011). Screening of bottle gourds (Lagenaria siceraria (Molina) Standley) genotypes with rootstock potential for watermelon production for resistance against Meloidogyne incognita (Kofoid \& White, 1919) Chitwood and Meloidogyne javanica (Treub, 1885) Chitwood. Turk. Entomol. Derg. 35(4), 687-697.

Soteriou, G.A., Papayiannis, L.C., and Kyriacou, M.C. (2016). Indexing melon physiological decline to fruit quality and vine morphometric parameters. Sci. Hortic. 203, 207-215. https://doi.org/10.1016/j.scienta.2016.03.032

Verzera, A., Dima, G., Tripodi, G., Condurso, C., Crinò, P., Romano, D., Mazzaglia, A. Lanza, C.M. Restuccia, C., and Paratore, A. (2014). Aroma and sensory quality of honeydew melon fruits (Cucumis melo L . subsp . melo var . inodorus H. Jacq .) in relation to different rootstocks. Sci. Hortic. 169, 118-124. 
Zhao, X., Guo, Y., Huber, D.J., and Lee, J. (2011). Grafting effects on postharvest ripening and quality of 1methylcyclopropene-treated muskmelon fruit. Sci. Hortic. 130(3), 581-587. https://doi.org/10.1016/j.scienta.2011.08.010 